\title{
The importance of an individual approach to Graves' hyperthyroidism
}

Tomasz Bednarczuk,, Affl

Corresponding Affiliation: Aff1

\begin{tabular}{|l||l||l||}
\hline \multicolumn{2}{|l||}{ ArticleInfo } \\
\hline \hline ArticleID & $:$ & 190 \\
\hline \hline ArticleDOI & $:$ & $10.1186 / 1756-6614-8-\mathrm{S} 1-\mathrm{A} 2$ \\
\hline \hline ArticleCitationID & $:$ & A2 \\
\hline \hline ArticleSequenceNumber & $:$ & 2 \\
\hline \hline ArticleCategory & $:$ & Meeting abstract \\
\hline \hline ArticleFirstPage & $:$ & 1 \\
\hline \hline ArticleLastPage & $:$ & 2 \\
\hline \hline ArticleHistory & $:$ & $\begin{array}{l}\text { RegistrationDate } \\
\text { OnlineDate }\end{array}$ \\
\hline \hline & & $\begin{array}{l}\text { Bednarczuk; licensee BioMed Central Ltd.2015 } \\
\text { This article is published under license to BioMed Central } \\
\text { Ltd. This is an Open Access article distributed under the } \\
\text { terms of the Creative Commons Attribution License } \\
\text { (http://creativecommons.org/licenses/by/4.0), which permits }\end{array}$ \\
\hline ArticleCopyright & $:$ & $\begin{array}{l}\text { unrestricted use, distribution, and reproduction in any } \\
\text { medium, provided the original work is properly cited. The } \\
\text { Creative Commons Public Domain Dedication waiver } \\
\text { (http://creativecommons.org/publicdomain/zero/1.0/) applies } \\
\text { to the data made available in this article, unless otherwise } \\
\text { stated. }\end{array}$ \\
\hline
\end{tabular}

Aff1

Department of Internal Medicine and Endocrinology, Medical University of Warsaw, Warsaw, Poland

Spring School of Thyroidology organized by the Polish Thyroid Association 2014: abstracts of invited lectures

Spring School of Thyroidology organized by the Polish Thyroid Association 2014

Miedzyzdroje, Poland

23-24 May 2014

Publication of this supplement was funded by the Polish Thyroid Association. The Supplement Editors declare that they have no competing interests.

Meeting abstracts

Andrzej Lewinski

Mariusz Stasiolek 
Graves' disease (GD) is an autoimmune disorder characterized by the presence of circulating autoantibodies that stimulate the thyroid hormone receptor (TSHR), resulting in hyperthyroidism and goiter. GD may affect also other organs, leading to Graves' orbitopathy, Graves' dermopathy and acropachy. It is likely that the extrathyroidal manifestations of GD are due to autoimmunity against antigens common to the thyroid and other affected organs (for example TSHR). Although its exact etiology remains to be established, GD is believed to result from a complex interaction between genetic, environmental and endogenous factors.

The clinical picture of GD is highly variable. Measurements serum levels of anti-TSHR autoantibodies (TRAb) and thyroid ultrasonography represent the most important diagnostic tests for GD.

Existing treatment modalities for Graves' hyperthyroidism includes antithyroid drugs (ATDs), radioactive iodine, and surgery. The use of ATDs as the initial treatment option in GD is well accepted. However, the optimal treatment duration and the predictive marker of remission after ATDs therapy are still controversial. A high relapse rate after a course of ATDs (60-70\%), implies the use of ablative treatments (radioactive iodine or surgery) that remove or decrease thyroid tissue leading to lifelong hypothyroidism. There is a lack of general agreement as to which therapy for Graves' hyperthyroidism is the best as none is ideal and all may have severe side effects. Moreover, none of these treatments targets the autoimmune disease process. Therefore the treatment plan should be established individually and carefully discussed with the patient. Hopefully novel agents that might act on the autoimmune disease process will be approved for Graves' hyperthyroidism. 